\title{
KARAKTERISASI KARBON AKTIF KULIT SINGKONG (Manihot utilissima) DENGAN VARIASI JENIS AKTIVATOR
}

\author{
CHARACTERIZATION OF ACTIVATED CARBON FROM CASSAVA PEELS (Manihot \\ utilissima) WITH DIFFERENT ACTIVATORS
}

\author{
Anugrah Rizqi Permatasari ${ }^{1)}$ Lia Umi Khasanah $^{2)}$ Esti Widowati $^{2)}$ \\ 1) Alumni Program Studi Teknologi Hasil Pertanian, Fakultas Pertanian UNS Surakarta \\ 2) Staf Pengajar Jurusan Teknologi Hasil Pertanian, Fakultas Pertanian UNS Surakarta \\ email: elfishyazayake@gmail.com
}

\begin{abstract}
Only small portion of cassava peel is used as animal feed mixture and the rest just discarded. The white parts of cassava peel contain for more than $50 \%$ carbon. The aims of this research was to determine the effect of different type activators and looked for the best activator for activated carbon characteristics made from cassava peel. This experiment used a complete randomized design with one factor. The applied factor was the type of activator, phosphoric acid $\left(\mathrm{H}_{3} \mathrm{PO}_{4}\right)$, potassium hydroxide $(\mathrm{KOH})$, and sodium chloride (NaCl). Data was analyzed using one-way ANOVA analysis test and continued by DMRT at 5\% level. The results showed that different types of activator gave effect to the characteristics of activated carbon from cassava peel include of moisture content, volatile matter content, and fixed carbon content but did not give effect to the characteristics of yield, ash content, and adsorptive Iodium capacity. The quality of activated carbon determined from activated carbon which has met defined standards or requirements, namely the Indonesian National Standard (SNI). Standard that used for it are SNI 06-3730-1995 for technical activated carbon. The chosen activator that gave the best characteristics of the activated carbon from cassava peel is sodium chloride (NaCl). This is because of the activated carbon that activated with sodium $\mathrm{NaCl}$ gave results that meet the characteristics of the activated carbon quality standards more than the other two types of activation.
\end{abstract}

Key words: activated carbon, carbonization, cassava peels waste, chemistry activation.

\section{ABSTRAK}

Kulit singkong yang merupakan limbah dari UKM dan industri yang berbahan baku singkong selama ini belum termanfaatkan, karena hanya sebagian kecil digunakan sebagai campuran pakan ternak dan selebihnya dibuang. Kulit singkong bagian dalam mengandung hampir 60\% karbon. Tujuan penelitian ini adalah untuk mengetahui pengaruh jenis aktivator dan mencari aktivator terbaik terhadap karakteristik karbon aktif kulit singkong. Penelitian ini dilaksanakan di Sub Lab Kimia Laboratorium Pusat Matematika dan Ilmu Pengetahuan Alam Universitas Sebelas Maret (UNS) Surakarta dan menggunakan Rancangan Acak Lengkap satu faktor yaitu jenis aktivator Asam Fosfat $\left(\mathrm{H}_{3} \mathrm{PO}_{4}\right)$, Potasium Hidroksida $(\mathrm{KOH})$, dan Natrium Klorida $(\mathrm{NaCl})$ dengan dua kali ulangan sampel dan dua kali ulangan analisis. Analisis data menggunakan uji analisis one way ANOVA dilanjutkan uji DMRT pada taraf 5\%. Hasil analisis menunjukkan bahwa penggunaan jenis aktivator yang berbeda memberikan pengaruh pada karakteristik karbon aktif kulit singkong yaitu kadar air, kadar zat terbang (bagian yang hilang pada pemanasan) dan kadar karbon namun tidak memberikan pengaruh untuk karakteristik rendemen, kadar abu, dan daya serap terhadap Iod. Karbon aktif yang baik adalah karbon aktif yang telah memenuhi standar atau persyaratan yang ditetapkan, yaitu Standar Nasional Indonesia (SNI). SNI yang digunakan adalah SNI 06-3730-1995 untuk arang aktif teknis. Aktivator terpilih yang memberikan hasil karakteristik karbon aktif terbaik adalah natrium klorida $(\mathrm{NaCl})$. Hal ini karena karbon aktif yang diaktivasi $\mathrm{NaCl}$ memberikan hasil karakteristik yang sudah memenuhi standar mutu karbon aktif lebih banyak daripada kedua jenis aktivator yang lain.

Kata kunci: aktivasi kimia, karbon aktif, karbonisasi, limbah kulit singkong

\section{PENDAHULUAN}

Singkong (Manihot utilissima) adalah salah satu jenis tanaman berkarbohidrat tinggi yang banyak tumbuh di Indonesia. Seiring dengan berkembangnya diversifikasi produk untuk singkong, maka berkembang juga berbagai jenis usaha yang menggunakan singkong sebagai bahan baku. Limbah utama dari industri pengolahan singkong adalah kulitnya. Persentase kulit singkong bagian dalam dapat mencapai $15 \%$ dari berat total singkong. Menurut Kurniasih (2002), kulit singkong selama ini hanya dibuang begitu saja, atau masih sebatas hanya untuk makanan ternak. Kulit singkong atau ubi kayu merupakan limbah dari ubi kayu yang mengandung 59,31\% karbon. Dengan adanya kandungan karbon yang cukup tinggi maka kulit singkong dapat dimanfaatkan sebagai 
karbon aktif atau arang aktif alami. Karbon aktif merupakan salah satu bahan berpori yang mengandung $85-95 \%$ karbon dengan luas permukaan besar yang terdiri dari unsur karbon bebas dan masing - masing berikatan secara kovalen.

Proses aktivasi bertujuan untuk memperbesar pori pada karbon. Aktivasi yang umum digunakan ada dua yaitu aktivasi secara fisika dan secara kimia. Aktivasi secara kimia dapat dilakukan dengan menggunakan larutan kimia sebagai aktivator, antara lain hidroksida logam alkali garam - garam karbonat, klorida, sulfat, fosfat dari logam alkali tanah dan asam asam anorganik seperti $\mathrm{ZnCl}_{2}, \mathrm{NaCl}, \mathrm{H}_{3} \mathrm{PO}_{4}$, $\mathrm{H}_{2} \mathrm{~S}, \mathrm{H}_{2} \mathrm{SO}_{4}$, atau $\mathrm{KOH}$. Beberapa senyawa yang sering dan secara umum digunakan adalah $\mathrm{ZnCl}_{2}, \mathrm{KOH}$, dan $\mathrm{H}_{2} \mathrm{SO}_{4}$ (Sembiring dan Sinaga, 2003; Ikawati dan Melati, 2009). Tujuan dari penelitian ini adalah untuk mengetahui pengaruh jenis aktivator asam fosfat $\left(\mathrm{H}_{3} \mathrm{PO}_{4}\right)$, natrium klorida $(\mathrm{NaCl})$, dan potasium hidroksida $(\mathrm{KOH})$ terhadap karakteristik karbon aktif kulit singkong (rendemen, kadar air, kadar abu, kadar zat terbang, daya serap $\mathrm{I}_{2}$, fixed carbon) serta mencari aktivator yang memberikan hasil karakteristik terbaik terhadap karbon aktif dari kulit singkong.

\section{METODE PENELITIAN}

\section{Bahan}

Kulit singkong bagian dalam yang berwarna putih, larutan $\mathrm{KOH} 5 \%$, larutan $\mathrm{H}_{3} \mathrm{PO}_{4} 5 \%$, larutan $\mathrm{NaCl} 5 \%$, larutan $\mathrm{HCl} 0,5 \mathrm{~N}$, larutan $\mathrm{KOH} 0,5 \mathrm{~N}$, larutan $\mathrm{I}_{2} \quad 0,1 \mathrm{~N}$, Natriumtiosulfat $0,0981 \mathrm{~N}$, aquades, amilum $1 \%$.

\section{Alat}

Alat yang digunakan meliputi oven, furnace, hot plate, desikator, dan stirer magnetik.

\section{Tahapan penelitian}

1. Pencucian dan Pemotongan

Kulit singkong dibersihkan dan dicuci terlebih dahulu. Selanjutnya kulit singkong dipotong dengan ukuran 50 x 5 mm.

2. Pengeringan
Kulit singkong yang telah berukuran sama dikeringkan menggunakan oven pada suhu $120^{\circ} \mathrm{C}$ selama 24 jam.

3. Tahap aktivasi

Aktivasi dilakukan secara kimia dengan menggunakan tiga jenis larutan sebagai aktivator, yaitu larutan $\mathrm{KOH} 5 \%$, larutan $\mathrm{NaCl} 5 \%$, dan larutan $\mathrm{H}_{3} \mathrm{PO}_{4} 5 \%$. Proses ini dilakukan dengan merendam kulit singkong ke dalam larutan selama 1 jam pada suhu $50^{\circ} \mathrm{C}$ sambil diaduk menggunakan stirrer. Selanjutnya kulit singkong ditiriskan (Putranto dan Razif, 2005).

4. Pengovenan dan karbonisasi

Kulit singkong dikeringkan kembali dengan cara dioven pada suhu $120^{\circ} \mathrm{C}$ selama 24 jam. Selanjutnya dilakukan proses karbonisasi dengan cara kulit singkong dipanaskan dalam tanur selama 2 jam dengan suhu $300^{\circ} \mathrm{C}$ (Ikawati dan Melati, 2009).

5. Penetralan dan pengeringan

Kulit singkong yang telah dikarbonisasi kemudian dinetralkan. Kulit singkong yang diaktivasi dengan larutan $\mathrm{KOH} 5 \%$ dinetralkan dengan $\mathrm{HCl} 0,5 \mathrm{~N}$, sedangkan kulit singkong yang diaktivasi dengan $\mathrm{H}_{3} \mathrm{PO}_{4} 5 \%$ dinetralkan dengan $\mathrm{KOH} 0,5$ $\mathrm{N}$. Karbon aktif yang telah dinetralkan kemudian disaring lalu dicuci dengan aquades panas dan dingin secara bergantian hingga mencapai $\mathrm{pH}$ 6,5. Selanjutnya karbon aktif dikeringkan kembali dalam oven selama 2 jam dengan suhu $110^{\circ} \mathrm{C}$.

6. Identifikasi karakteristik karbon aktif

Dilakukan identifikasi karakteristik karbon aktif yang meliputi analisis rendemen, kadar air, kadar abu, daya serap terhadap Iod, kadar zat terbang (bagian yang hilang pada pemanasan), dan kadar karbon (fixed carbon).

Penelitian ini menggunakan Rancangan Acak Lengkap RAL satu faktor yaitu jenis aktivator. Analisis data menggunakan uji analisis one way ANOVA dilanjutkan dengan uji Duncan Multiple Range Test pada taraf signifikansi $\alpha=0,05$. 


\section{HASIL DAN PEMBAHASAN}

\section{Karakteristik Mutu Karbon Aktif}

Hasil analisis karakteristik mutu karbon aktif kulit singkong adalah sebagai berikut :

\section{Rendemen Karbon Aktif}

Penghitungan rendemen dilakukan untuk mengetahui persentase jumlah arang aktif yang dihasilkan dari bahan awal kulit singkong kering setelah melewati proses aktivasi dan karbonisasi. Dari Tabel 1. dapat dilihat rendemen arang aktif tertinggi sebesar $55,404 \%$ diperoleh dari perlakuan aktivasi $\mathrm{KOH}$ dan rendemen terendah sebesar 48,009 $\%$ diperoleh dari perlakuan aktivasi $\mathrm{H}_{3} \mathrm{PO}_{4}$.

Menurut Foo dan Lee (2010), pada penelitian preparasi karbon aktif dari petai (Parkia speciosa) dengan aktivasi kimia menggunakan Asam Fosfat $\left(\mathrm{H}_{3} \mathrm{PO}_{4}\right)$, rendemen yang dihasilkan cenderung rendah dan menurun. Berkurangnya persentase rendemen karbon aktif disebabkan oleh pemanasan suhu tinggi yang menyebabkan zat volatil dalam bahan banyak yang hilang dan senyawa fosfat yang terdapat dalam bahan juga ikut menghilang.

\section{Kadar Air}

Penghitungan kadar air pada arang aktif bertujuan untuk mengetahui sifat higroskopis (daya serap air) arang aktif. Kadar air tertinggi diperoleh pada sampel dengan aktivasi $\mathrm{KOH}$ sebesar 31,401\%, sedangkan kadar air terendah terdapat pada sampel dengan aktivasi $\mathrm{NaCl}$ sebesar 16,572\%.

Afidah (2010) dengan penelitian pemanfaatan karbon aktif bagasse dengan aktivasi $\mathrm{NaOH}$ dan $\mathrm{H}_{2} \mathrm{SO}_{4}$ menyebutkan bahwa hasil analisis kadar air untuk karbon aktif yang diaktivasi asam dan basa memberikan hasil yang berbeda. Karbon aktif yang diaktivasi asam $\left(\mathrm{H}_{2} \mathrm{SO}_{4}\right)$ memiliki kadar air yang lebih rendah dibanding karbon aktif teraktivasi basa $(\mathrm{NaOH})$, hal ini dikarenakan kompleks oksigen yang rusak saat aktivasi $\mathrm{H}_{2} \mathrm{SO}_{4}$ lebih banyak sehingga kepolaran dari karbon teraktivasi $\mathrm{H}_{2} \mathrm{SO}_{4}$ lebih rendah.

Persentase kadar air pada ketiga sampel masih berada di bawah standar SNI 06-37301995 tentang arang aktif teknis, yaitu maksimal kadar air pada arang aktif adalah $15 \%$

\section{Kadar Abu}

Abu adalah oksida - oksida logam dalam arang yang terdiri dari mineral yang tidak dapat menguap (non-volatile) pada proses pengabuan. Kandungan abu sangat berpengaruh pada kualitas karbon aktif. Keberadaan abu yang berlebihan dapat menyebabkan terjadinya penyumbatan pori pori karbon aktif sehingga luas permukaan karbon aktif menjadi berkurang (Scroder dalam Ikawati dan Melati, 2009). Penetapan kadar abu arang aktif dilakukan untuk mengetahui kandungan oksida logam dalam arang aktif (Sutapa dan Pujiarti, 2005).

Hasil persentase kadar abu pada ketiga sampel, ketiganya memenuhi standar kualitas kadar abu untuk arang aktif menurut SNI 063730-1995, yaitu dibawah $10 \%$. Penggunaan $\mathrm{NaCl}$ sebagai bahan pengaktif memberikan karakteristik kadar abu terbaik karena kandungan kadar abu yang paling rendah.

\section{Kadar Zat Terbang (Bagian yang Hilang pada Pemanasan)}

Penetapan atau perhitungan kadar zat terbang (bagian yang hilang pada pemanasan) atau kadar zat mudah menguap bertujuan untuk mengetahui kandungan senyawa yang mudah menguap yang terkandung dalam arang aktif. Dari hasil penelitian diketahui kadar zat terbang tertinggi sebesar 21,706\% pada sampel dengan aktivasi $\mathrm{H}_{3} \mathrm{PO}_{4}$, sedangkan kadar zat terbang yang paling rendah terdapat pada sampel dengan aktivasi $\mathrm{NaCl}$ sebesar $6,683 \%$.

Hasil karakterisasi kadar zat terbang (bagian yang hilang pada pemanasan) pada ketiga sampel, ketiganya memenuhi kualitas standar SNI 06-3730-1995 tentang arang aktif teknis, yaitu bagian yang hilang pada pemanasan maksimal $25 \%$.

Menurut Sutapa dan Pujiarti (2005), pada penelitian mutu arang aktif dari limbah kayu mahoni yang diaktivasi dengan basa kuat dan garam memberikan hasil bahwa arang aktif yang diaktivasi dengan basa menghasilkan persentase kadar zat mudah menguap sebesar 26,2 \%, lebih tinggi daripada kadar zat mudah menguap pada sampel aktivasi larutan garam dan lebih tinggi daripada batas maksimal persyaratan SNI 06-3730-1995. 
Tabel 1. Karakteristik Mutu Karbon Aktif Kulit Singkong

\begin{tabular}{|c|c|c|c|c|}
\hline \multirow{2}{*}{ Karakteristik } & \multicolumn{4}{|c|}{ Jenis Aktivator } \\
\hline & $\mathrm{NaCl}$ & \multicolumn{2}{|c|}{$\mathrm{H}_{3} \mathrm{PO}_{4}$} & $\mathrm{KOH}$ \\
\hline Rendemen $(\%)$ & $51,147^{\mathrm{a}} \pm 1,05716$ & \multicolumn{2}{|c|}{$48,009^{\mathrm{a}} \pm 1,3124$} & $55,404^{\mathrm{a}} \pm 4,0$ \\
\hline Kadar air $(\%)$ & $16,572^{\mathrm{a}} \pm 1,5906$ & \multicolumn{2}{|c|}{$19,188^{\mathrm{b}} \pm 0,4781$} & $31,401^{\mathrm{c}} \pm 2,08$ \\
\hline Kadar abu (\%) & $6,464^{\mathrm{a}} \pm 0,4152$ & \multicolumn{2}{|c|}{$7,171^{\mathrm{a}} \pm 0,1701$} & $9,740^{\mathrm{a}} \pm 6,82$ \\
\hline Kadar zat terbang $(\%)$ & $6,683^{\mathrm{a}} \pm 1,2973$ & \multicolumn{2}{|c|}{$21,706^{\mathrm{b}} \pm 0,7150$} & $9,021^{\mathrm{a}} \pm 3,50$ \\
\hline Kadar karbon $(\%)$ & $70,281^{\mathrm{b}} \pm 0,2365$ & \multicolumn{2}{|c|}{$51.936^{\mathrm{a}} \pm 0.0153$} & $49,839^{\mathrm{a}} \pm 7,3$ \\
\hline Adsorpsi Iod (mg/g) & $1208,831^{\mathrm{a}} \pm 25,1556$ & \multicolumn{2}{|c|}{$1177,709^{\mathrm{a}} \pm 7,1867$} & $7,131^{\mathrm{a}} \pm 41,44$ \\
\hline \multicolumn{5}{|c|}{$\begin{array}{l}\text { Keterangan : Angka yang diikuti huruf yang sama menunjukkan tidak berbeda nyata pada taraf } \alpha 0,05 \text { (berlak } \\
\text { yang sama). }\end{array}$} \\
\hline \multicolumn{5}{|c|}{ Tabel 2. Persyaratan Arang Aktif Menurut SNI 06-3730-1995 } \\
\hline \multirow{2}{*}{\multicolumn{2}{|c|}{ Uraian }} & \multirow{2}{*}{ Satuan } & \multicolumn{2}{|c|}{ Persyaratan } \\
\hline & & & Butiran & Serbuk \\
\hline \multicolumn{2}{|c|}{ Bagian yang hilang pada pemanasan $950^{\circ} \mathrm{C}, \%$} & - & Maks. 15 & Maks. 25 \\
\hline \multicolumn{2}{|c|}{ Air, $\%$} & - & Maks. 4,4 & Maks. 15 \\
\hline \multicolumn{2}{|l|}{ Abu, \% } & - & Maks 2,5 & Maks. 10 \\
\hline \multicolumn{2}{|l|}{ Daya serap terhadap $\mathrm{I}_{2}$} & $\mathrm{Mg} / \mathrm{g}$ & Min. 750 & Min. 750 \\
\hline \multicolumn{2}{|l|}{ Karbon aktif murni, \% } & - & Min. 80 & Min. 65 \\
\hline
\end{tabular}

Sumber : Badan Standardisasi Nasional (1995)

\section{Kadar Karbon (Fixed Carbon)}

Kadar karbon (fixed carbon) merupakan banyaknya karbon terikat yang terdapat dalam karbon aktif tersebut (Sutapa dan Pujiarti, 2005). Kadar karbon tertinggi diperoleh dari sampel dengan aktivasi $\mathrm{NaCl}$ sebesar 70,281\%. Sedangkan kadar karbon terendah pada sampel dengan aktivasi $\mathrm{KOH}$ yaitu sebesar 49,839\%. Besar kecilnya kadar karbon ini dipengaruhi oleh jumlah kadar air, kadar abu, dan kadar zat mudah menguap pada bahan.

Berdasarkan standar kualitas untuk arang aktif, SNI 06-3730-1995 (Tabel 2) terhadap kadar karbon, persyaratan untuk kadar karbon adalah minimal 65\%. Sehingga semakin tinggi fixed carbon yang dihasilkan maka semakin baik arang aktif tersebut. Pada penelitian ini, sampel yang memenuhi standar kualitas adalah sampel dengan aktivasi $\mathrm{NaCl}$ dengan kadar karbon sebesar 70,281\%. Sedangkan untuk kedua sampel yang lain persentase kadar karbon masih berada di bawah standar yang diharuskan. Menurut Zamrudy (2008) Semakin rendah kadar abu maka kemurnian karbon aktif yang dihasilkan akan semakin tinggi.

\section{Adsorpsi Iod}

Daya serap terhadap Iod (adsorpsi Iod) mengindikasikan kemampuan karbon aktif untuk mengadsorp komponen dengan berat molekul rendah (Suzuki dalam Ikawati dan Melati, 2009). Karbon aktif dengan kemampuan menyerap Iod tinggi berarti memiliki luas permukaan yang lebih besar dan juga memiliki struktur mikro dan pori yang lebih besar (Afidah, 2010). Tabel 1 menunjukkan persentase Iod yang diserap oleh ketiga sampel besarnya tidak terlalu jauh berbeda. Persentase daya serap Iod yang paling besar oleh sampel dengan aktivasi $\mathrm{KOH}$ yaitu sebesar $15,665 \%$, sedangkan persentase paling rendah pada sampel aktivasi $\mathrm{H}_{3} \mathrm{PO}_{4}$ yaitu sebesar 11,723\%.

Berdasarkan standar SNI 06-3730-1995 tentang arang aktif teknis, untuk daya serap terhadap Iod disyaratkan jumlah minimal 750 $\mathrm{mg} / \mathrm{g}$. Jika dibandingkan dengan persyaratan tersebut, maka ketiga sampel sudah memenuhi standar. Daya serap terhadap Iod pada sampel yang diaktivasi $\mathrm{NaCl}$ adalah sebesar 1208,8303 mg/g, sampel diaktivasi $\mathrm{H}_{3} \mathrm{PO}_{4}$ sebesar $1177,7085 \mathrm{mg} / \mathrm{g}$, dan sampel yang diaktivasi $\mathrm{KOH}$ sebesar 1217,1307 $\mathrm{mg} / \mathrm{g}$. Nilai daya serap terhadap Iod yang paling besar dihasilkan oleh sampel yang diaktivasi $\mathrm{KOH}$ namun selisihnya tidak 
terlalu jauh berbeda dengan kedua sampel yang lain.

Menurut penelitian Sutapa dan Pujiarti (2005) yang menganalisa mutu arang aktif dari limbah kayu mahoni, besarnya daya serap arang aktif terhadap iodium kemungkinan disebabkan senyawa hidrokarbon yang tertinggal pada permukaan arang terbuang pada waktu aktivasi, sehingga permukaannya menjadi aktif.

\section{Aktivator Terpilih}

\section{Rendemen}

Pada Tabel 1. dapat dilihat bahwa ketiga jenis aktivator menghasilkan persentase rendemen yang berbeda. Semakin tinggi persentase rendemen yang dihasilkan, maka semakin baik karbon aktif tersebut. Dari ketiga jenis aktivator, yang menghasilkan rendemen tertinggi sebesar 55,404\% adalah karbon aktif diaktivasi KOH. Namun hasil dari ketiga sampel tersebut tidak menunjukkan ada beda nyata tiap sampel, sehingga dapat dikatakan bahwa jenis aktivator tidak berpengaruh pada hasil rendemen karbon aktif.

\section{Kadar air}

Persentase kadar air maksimal yang terkandung dalam karbon aktif sesuai dengan Standar Nasional Indonesia (SNI) 06-37301995 adalah 15\%. Hasil kadar air dari ketiga jenis sampel menunjukkan bahwa kandungan kadar air ketiganya belum memenuhi standar, karena masih berada diatas $15 \%$. Namun hasil persentase kadar air yang paling mendekati batas persyaratan adalah kadar air pada sampel dengan aktivator $\mathrm{NaCl}$, yaitu sebesar $16,572 \%$. Adanya beda nyata antar sampel pada ketiga sampel tersebut menunjukkan bahwa jenis aktivator mempengaruhi kandungan kadar air pada karbon aktif.

\section{Kadar abu}

Berdasarkan persyaratan Standar Nasional Indonesia (SNI) batas kadar abu yang terkandung pada karbon aktif adalah maksimal 10\%. Kadar abu untuk ketiga sampel karbon aktif ketiganya sudah memenuhi standar dari SNI yaitu dibawah
10\%. Semakin rendah persentase kadar abu maka semakin baik karbon aktif tersebut.

Pada ketiga sampel dengan aktivator yang berbeda tersebut, ketiganya tidak menunjukkan ada beda nyata pada tiap sampel. Hal ini menunjukkan bahwa jenis aktivator tidak mempengaruhi kadar abu yang dihasilkan.

\section{Kadar zat terbang}

Kadar zat terbang (bagian yang hilang pada pemanasan) pada ketiga sampel sudah memenuhi Standart Nasional Indonesia (SNI) 06-3730-1995 untuk arang aktif, dimana persyaratan untuk kadar zat terbang adalah maksimal $25 \%$. Antara sampel yang diaktivasi $\mathrm{NaCl}$ dan sampel yang diaktivasi $\mathrm{KOH}$ tidak ada beda nyata antar kedua saampel tersebut, namun keduanya berbeda nyata dengan sampel yang diaktivasi $\mathrm{H}_{3} \mathrm{PO}_{4}$. Aktivator terpilih untuk karatekteristik kadar zat terbang adalah aktivator $\mathrm{NaCl}$ dan aktivator $\mathrm{KOH}$. Hal ini karena sampel dari kedua jenis aktivator tersebut yang memenuhi persyaratan dari SNI dan keduanya tidak berbeda nyata antar sampel.

\section{Kadar karbon}

Batas minimal persentase kadar karbon adalah 65\%. Dari ketiga sampel, yang menghasilkan kadar karbon tertinggi adalah sampel yang diaktivasi $\mathrm{NaCl}$ yaitu sebesar $70,281 \%$. Hasil persentase kadar karbon aktivasi $\mathrm{NaCl}$ ini sudah memenuhi batas minimal persyaratan dari SNI 06-3730-1995. Sedangkan untuk kadar karbon dari kedua sampel dengan aktivator $\mathrm{H}_{3} \mathrm{PO}_{4}$ dan $\mathrm{KOH}$ persentasenya masih dibawah batas minimal $65 \%$.

Sampel yang diaktivasi $\mathrm{NaCl}$ juga memberikan hasil yang beda nyata terhadap kedua sampel yang lain. Sedangkan pada sampel yang diaktivasi $\mathrm{KOH}$ tidak beda nyata dengan sampel yang diaktivasi $\mathrm{H}_{3} \mathrm{PO}_{4}$. Sehingga aktivator terpilih untuk karakteristik kadar karbon adalah aktivator $\mathrm{NaCl}$.

\section{Adsorpsi Iod}

Persyaratan daya serap Iod untuk karbon aktif berdasarkan SNI 06-3730-1995 adalah minimal $750 \mathrm{mg} / \mathrm{g}$. Bila dibandingkan dengan ini maka daya serap Iod pada ketiga sampel 
sudah memenuhi syarat, karena hasil daya serap Iod pada ketiga sampel antara $1177,7085 \sim 1217,1307$ mg/g. Semakin tinggi daya serap karbon aktif terhadap zat Iod, maka semakin baik karbon aktif tersebut. Ketiga sampel dengan aktivator yang berbeda tersebut juga tidak menunjukkan beda nyata antar tiap sampelnya. Hal ini menunjukkan bahwa jenis aktivator tidak mempengaruhi kemampuan karbon aktif dalam menyerap zat Iod.

\section{KESIMPULAN}

1. Penggunaan jenis aktivator yang berbeda memberikan pengaruh pada karakteristik karbon aktif yaitu kadar air, kadar zat terbang (bagian yang hilang pada pemanasan), dan kadar karbon namun tidak mempengaruhi rendemen, kadar abu, dan daya serap terhadap Iod.

2. Aktivator terpilih yang digunakan sebagai aktivator pada karakteristik mutu karbon aktif kulit singkong adalah aktivator larutan $\mathrm{NaCl}$.

\section{DAFTAR PUSTAKA}

Afidah, S. 2010. Pemanfaatan Karbon Aktif Bagasse dengan Aktivasi $\mathrm{NaOH}, \mathrm{H}_{2} \mathrm{SO}_{4}$ untuk Menurunkan Kadar Protein dalam Limbah Cair Tahu. Skripsi Fakultas Matematika dan Ilmu Pengetahuan Alam Universitas Sebelas Maret Surakarta. Surakarta.

Badan Standardisasi Nasional. 1995. Standar Nasional Indonesia Arang Aktif Teknis. SNI 06-3730-1995. ICS 75.160.10. Jakarta.
Foo, P. Y. L. dan L. Y. Lee. 2010. Preparation of Activated Carbon from Parkia Speciosa Pod by Chemical Activation. Proceedings of the World Congress on Engineering and Computer Science 2010 Volume II, October 2010. San Fransisco.

Ikawati dan Melati. 2009. Pembuatan Karbon Aktif dari Limbah Kulit Singkong UKM Tapioka Kabupaten Pati. Prosiding Seminar Nasional "Peran Teknik Kimia dalam Menjamin Ketahanan Pangan dan Energi Nasional" Seminar Nasional Teknik Kimia Indonesia (SNTKI) ISBN 978979-98300-1-2. Jakarta.

Kurniasih, T. N. 2002. Pembuatan Asam Oksalat dari Kulit Ubi Kayu Varietas Randu dengan Larutan $\mathrm{NaOH}$. Laporan Penelitian Universitas Muhammadiyah Surakarta. Surakarta.

Sembiring, M. T. dan T. S. Sinaga. 2003. Arang Aktif (Pengenalan dan Proses Pembuatannya). Skripsi. USU Digital Library Digitized 2003. Sumatera Utara.

Sutapa, J. P. G. dan R. Pujiarti. 2005. Mutu Arang Aktif dari Limbah Kayu Mahoni (Swietenia macrophylla King) sebagai Bahan Penjernih Air. Jurnal Ilmu dan Teknologi Kayu Tropis. Volume 3 No.2 tahun 2005.

Zamrudy, W. 2008. Pembuatan Karbon Aktif dari Ampas Biji Jarak Pagar (Jatropha curcas Linn). Jurnal Teknologi Separasi. Volume 1 Nomor 2 November 2008 ISSN 1978-8789. 